\title{
Migration by Sea: Protection of Asylum Seekers
}

\author{
FARAH NURUL AYU BINTI IZANY \\ ROHANI ABDUL RAHIM \\ ANNALISA YAHANAN \\ AZIZAH LANDA
}

\begin{abstract}
Protection of asylum seekers migrating by sea are reflected in international law on refugees, international maritime law, international human rights and international criminal law. Asylum seekers shared their mode of travel via sea with many types of migrant, and most of the time they are being referred to as "mixed migration" or "irregular maritime migration" or "boat people". They have the rights to family life and basic needs and assistance for shelter, food, legal, medical and psychosocial assistance from the UNHCR and the relevant organizations. The right also includes the right to seek and to enjoy protection from persecution(Article 14 of the Universal Declaration of Human Rights) in other countries of asylum. The asylum seeker may be recognized as a refugee when the person's circumstances fall into the definition of "refugee" according to the 1951 Convention relating to the Status of Refugees (1951 Convention) or other refugee laws. The issues of asylum seekers migrating by sea are complex as a result of conflicts between provisions of different international legal regimes. Aiding those in peril at sea is an obligation codified under several conventions relating to international maritime law such as the United Nations Convention on the Law of the Sea of 1982 (UNCLOS), the International Convention for the Safety of Life at Sea of 1974 (SOLAS) as amended, the International Convention on Maritime Search and Rescue of 1979 (SAR) as amended, and the 1958 Convention on the High Sea (to the extent that it has not been superseded by UNCLOS). Therefore, this write up examines provisions from different strands of international law that bear asylum seekers who are migrating by sea which includes the scope of search and rescue, and disembarkation of asylum seeker on coastal States. Simultaneously it also attempts to explore Malaysia attitudes towards asylum seekers migrating by sea.
\end{abstract}

Keywords: Asylum seekers; migration by sea; rescue

\section{INTRODUCTION}

Asylum seekers are amongst those people who choose to leave home by using the sea route to enter into another country in order to seek protection as refugees. The image of the death of Alan Kurdi, three, who was wearing a red T-shirt and denim shorts, lying face-down in the sand, after the boat he took with his family capsized in the Mediterranean sea is shocking and a reminder of the dangers children and families are taking in search for a better life.

When the refugee crisis begin in the early 1950s and continued into late 1970s, rescue at sea did not involve many issues that exist today. During that time, it was possible for the rescued refugees to have their claims processed in the next available port of call or the rescuing ship. They could even find protection in that port of call, in a place where the ship was registered or in another place where the refugees previous had ties ${ }^{1}$.

However, the smooth process reached a critical point in the late 1970s after the war in Vietnam broke out. At this time, many Vietnamese refugees took the South China Sea in boats, most of which were not seaworthy and risked becoming a target brutal criminals who attacked, looted and disabled boats and often abducted or took the lives of passengers. Merchant vessels, sailing through these waters and encountered these troubled boats followed the usual practice of rescuing the passengers and seeking to disembark them in the next port of call. However, when the rescued refugees arrived in the nearby coastal States such as Malaysia, Australia and Thailand, these countries refused to allow the passenger disembarkation. ${ }^{2}$ 
Meanwhile, as early as 1975, the Executive Committee (EXCOM) of the United Nations High Commissioner for Refugees (UNHCR) recognized the problems associated with the practical issues raised when rescued asylum seekers arrive in a state's territorial sea and seek to come ashore. Over the years a number of measures have been promulgated by UNHCR to address the problem, under its mandate of 'providing international protection to refugees' and 'seeking permanent solutions for the problems of refugees by assisting governments.'

In 1978, the UNHCR brokered an agreement under which the coastal States would allow these "boat people" to come ashore if other states (mainly Western) agreed to resettle all such people within 90 days of their disembarkation. However, the arrangement did not work as smoothly as hoped. Ships found themselves subject to lengthy and costly delays as coastal states demanded that specific resettlement provisions be put in place prior to disembarkation. Ship owners who respected the traditions and laws governing rescue at sea bore all the direct costs of making a rescue. Refugee boats arrived with dead and dying passengers throughout the early $1980 \mathrm{~s}$, and survivors reported that 80-90 percent of the ships they hailed refused to respond to distress calls. Subsequently, the ratio of rescues to arrivals continued to shrink.

In 1984-1985, UNHCR put in a place a number of emergency measures. They appealed successfully for more resettlement places to be offered and streamlined the procedures for matching up arrival and resettlement places. They established a scheme to reimburse owners for the direct costs of rescue, issued guidelines for ship owners and masters on the operational aspects of rescue and sent out maritime radio messages explaining rescue procedures and appealing for ships to respond to boats in distress. They also began issuing public commendations to vessels that rescued refugees. By 1985, rescue was again on the rise. The crisis was slowly defused as the new measures took hold and the number of boat departures from Vietnam gradually declined.

However, the 1990s brought another upsurge in the number of people taking the sea in an attempt to reach safer countries that provided more opportunities. The refugees of 1990s were mostly from African and Eastern Asian nations seeking to sail to Europe and America. Tighter controls at borders and ports-of-entry were associated with the unintended consequence of illegal professional smuggling. High profit in this business attracted organized crime to smuggle people, thereby increasing the risks involved.

The involvement of organized criminal activity forced a stricter response from both officials and the public toward people coming from the boat. The authorities of the countries of destination were often inadvertently complicit with criminals by seeking to categorize all arriving refugees as economic migrants, despite the efforts of many to declare their intention to claim asylum from authoritarian and/or lawless countries. Despite the dangers, people continued to embark, from places such as North Africa, the Caribbean and Asia. Countries such as Turkey and Indonesia have served as major staging points for smugglers assembling passengers from many countries.

The toll in human life and property has been significantly high. Estimates of the number of people drowned in the 
straits between Spain and North Africa in the 1990s range from 600 to 3,000. More than 22,500 migrants have reportedly died or disappeared globally since 2014, more than half of them perishing while attempting to cross the Mediterranean. ${ }^{3}$

In the recent case of Rohingya refugees, as many as 112,500 believed to have travelled by sea to Malaysia from 2012 until $2015^{4}$. While, some Rohingya refugees who were rescued by Achenese in Indonesia in May 2015 were believed to have reached Malaysia in 2016 by crossing the Malacca Strait. That crossing, though relatively cheap and short, remained deadly, with over 100 migrants dying in capsizes between January 2016 and January 2017, including one in November that killed 54 Indonesian migrant workers.

The issues relating to asylum seeker migrating by sea are complex and affecting states and international organizations such as the UNHCR, International Maritime Organization (IMO) and International Organization for Migration (IOM). The complexity occurred as a result of conflicts between provisions of different legal regimes in relation to asylum seekers migrating by sea such as international maritime law, international law on refugees, international human rights law and international criminal law.

\section{DEFINING ASYLUM SEEKERS}

Asylum seeker is a person who seeks safety from persecution or serious harm in a country other than his or her own and awaits a decision on the application for refugee status under relevant international and national instruments. ${ }^{5}$ In simple words, an asylum seeker is someone who says he or she is a refugee, but whose claim has not yet been definitively evaluated. Not every asylum-seeker will ultimately be recognized as a refugee, but every refugee is initially an asylumseeker. ${ }^{6}$
According to the international refugee law, "people who are forced to flee their homes due to persecution, whether on an individual basis or as part of a mass exodus due to a political, religious, military or other problem are known as refugees."7 An asylum seeker may be a refugee, a displaced person or a migrant, such as an economic migrant. A person becomes an asylum seeker by making a formal application for the right to remain in another country and keeps the status until the application is concluded.

The asylum seeker may later be recognized as a refugee and given refugee status if the person's circumstances fall into the definition of "refugee" according to the 1951 Convention relating to the Status of Refugees (1951 Convention) or other refugee laws. Under the 1951 Convention, a refugee is someone who has fled their own country and cannot return due to a well-founded fear of persecution. The persecution may relate to a person's race, religion, nationality, membership of a particular social group, or political opinion. ${ }^{8}$ It is not even accurate to regard all people without papers who are travelling by sea as having an "illegal" status. ${ }^{9}$ They are subject to the jurisdiction of the flag state and the state of their own citizenship, and it is of course a legal right under the 1951 Convention to arrive in another jurisdiction without permission in order to claim asylum. States are under international obligation to consider claims for asylum and not to immediately return asylum seekers to the countries they have fled from. ${ }^{10}$

The relevant immigration authorities of the country of asylum determine whether the asylum seeker will be granted protection and becomes an officially recognized refugee or whether asylum is refused and the person becomes an illegal immigrant. In case of a negative decision, the person must leave the country and may be expelled, as may any nonnational in an irregular or unlawful situation, unless permission to stay is 
provided on humanitarian or other related grounds. The lack of opportunities to legally access the asylum procedures can force asylum seekers to undertake expensive and hazardous attempts at illegal entry.

\section{TYPES OF ASYLUM SEEKERS}

\section{(a) Convention Refugee Status}

As of April 2015, there were 145 parties to the 1951 Convention and 146 to the 1967 Protocol. ${ }^{11}$ These States are bound by an obligation under international law to grant asylum to people who fall within the definition of 1951 Convention and 1967 Protocol relating to the Status of Refugees (the 1967 Protocol). The refugee definitions of 1951 Convention and the 1967 Protocol are the strictest and most exclusive and persons who fall within this definition are called "Convention refugees' and their status is called "Convention refugee status."12 People who do not fall within this definition may still granted complementary forms of protection, if they fall within other refugee definitions.

The practical determination of whether a person is a refugee or not is most often left to certain government agencies within the host country. In some countries, for example like Malaysia, the refugee status determination (RSD) is done by the UNHCR. ${ }^{13}$ The burden of substantiating an asylum claim lies with the claimant, who must establish that they qualify for protection.

\section{(b) Complementary forms of protection}

It is very important to note that everyone has a right to seek and to enjoy in other countries of asylum from persecution (Article 14 of the Universal Declaration of Human Rights). As such, even though the refugee definition under the 1951 Convention is universally binding, still there are many other definitions according to which protection may be offered to people who do not fall within this definition.

Subsidiary protection is an international protection for persons seeking asylum but do not qualify as refugees. It is an option to get asylum for those who do not have a well- founded fear of persecution, but do indeed have a substantial risk to be subjected to torture or to a serious harm if they returned to their country of origin, for reasons include war, violence, conflict and massive violations of human rights.

In European Law, Directive 2004/83/EC states the minimum standards for qualifying for subsidiary protection status in relation to a non-European Union national or a stateless person. Under this law, a person eligible for subsidiary protection status means a third country national or stateless who would face a real risk of suffering serious harm if he or she return to the country of origin. Serious harm is defined under Article 15 of the Directive 2004/83/EC as the risk of: "(a) death penalty or execution; or (b) torture or inhuman or degrading treatment or punishment of an applicant in the country of origin; or (c) serious and individual threat to a civilian's life or person by reasons of indiscriminate violence in situations of international or internal armed conflict."

However, the Directive 2004/83/EC has been superseded by the Directive 2011/95/EU of the European Parliament and of the Council of 13 December 2011 on standards for the qualification of third-country nationals or stateless persons as beneficiaries of international protection, for a uniform status for refugees or for persons eligible for subsidiary protection, and for the content of the protection granted (recast). ${ }^{14}$

Some countries offer "asylum visas" which are a safe and legal way to reach the country where asylum will be claimed. Temporary protection visas 
(TPV) are given to asylum seekers who are found to be in need of protection in Australia and they are required to reapply for it every three years. ${ }^{15}$ TPVs were first introduced in Australia in 1999 and were eventually removed in 2008 and replaced by the Humanitarian Stay Temporary Visa (HSTV) that leads to the Temporary Humanitarian Concern Visa (THCV) and these are similar to TPVs. ${ }^{16}$

\section{STATUS DETERMINATION PROCESS}

The relevant immigration authorities of the country of asylum determine whether the asylum seeker will be granted protection and becomes an officially recognized refugee or whether asylum is refused and the person becomes an illegal immigrant. For example, the European Union has established the "Asylum Procedures Directive" that sets common procedures for the European Union Member States for granting and withdrawing international protection $^{17}$. It provides people fleeing persecution or serious harm and applying for international protection in the European Union with a high level of safeguards and enables Member States to operate efficient asylum procedures. The Asylum Procedures was adopted by the European Parliament and the Council in 2013 and was to be transposed into Member States' national legislations by July 2015. It repealed Council Directive 2005/85/CE on minimum standards on procedures in Member States for granting and withdrawing refugee status. However, the European Commission has presented a Proposal for a new Asylum Procedure Regulation in July 2016, intended to replace Directive 2013/32/EU. The Proposal aims at establishing a truly common procedure for international protection which is fair and efficient, while removing incentives for asylum shopping and secondary movements between Member States.

Asylum seekers may be given refugee status on a group basis. Refugees who went through the "group status determination" are also known as "prima facie refugees." $" 18$ it is normally done when the reasons for seeking refugee status are generally well known. Group status determination is more readily done in States that not only have accepted the refugee definition of the 1951 Convention, but also use a refugee definition that includes "people fleeing indiscriminate or generalized violence."

Refugee status is also determined using individual assessment ordinarily on an individual basis by ascertaining the facts of a case taking into account the claimant's personal circumstances evaluated against all the evidence and applying the relevant refugee definition to such facts. ${ }^{19}$ Individual asylum interviews are conducted to establish whether the person has sufficient reasons for seeking asylum.

Asylum seekers has the right to challenge a rejection of asylum application. In the United Kingdom (UK), asylum seekers have a right of appeal to the First Tier Tribunal if their claim is refused. ${ }^{20}$ They are allowed to remain in the UK while waiting for their appeals to be decided. In New Zealand, the appeal of asylum application is being heard in the Immigration and Protection Tribunal. ${ }^{21}$

\section{RIGHTS OF ASYLUM SEEKERS}

While waiting for the decision on the asylum application, it is the basic right that asylum seekers have the rights to be treated with humanity. ${ }^{22}$ Other than that, asylum seekers have the right to family life, so they must be allowed to reunite with their families. In Greece, asylum seekers have the right to receive information about their asylum application, rights and duties in a language they understand. ${ }^{23}$ They also have the right to access basic assistance including shelter, food, legal, medical and psychosocial assistance from the UNHCR and other organizations. 
However, asylum seekers have limited rights in the country of asylum. In some countries, asylum seekers are not allowed to move freely within the country, even access to healthcare is limited. In the European Union countries, those who have yet to be granted official status as refugees and are still within the asylum process have some restricted rights to healthcare access. ${ }^{24}$ Asylum seekers in the UK are not allowed to work or claim benefits and not even to volunteer. Some asylum seekers are kept in immigration detention centres while process claim. Even though asylum seekers are facing destitution, they are not allowed to work and only receive minimal or no financial support. As a result, asylum seekers are reliant on charities and their limited social networks to make ends meet. ${ }^{25}$ In some countries, support ends immediately after given refugee status.

\section{PROTECTION OF ASYLUM SEEKERS MIGRATING BY SEA}

Migration by sea mostly consist of asylum seekers or other type of migrants crossing the sea borders ${ }^{26}$ in attempt to reach the closest destination by ships or boats. Some author may refer migration by sea as "maritime migration" 27 " or "boat migration" 28 or "mixed migration." Irregular maritime migration is mostly "mixed" as it consists of flows of people who are on the move for different reasons but who share the same routes, modes of travel and vessels and they cross land and sea borders without authorization, frequently with the help of people smugglers. However, all of these movements include at least some refugees, asylum seekers or other people of concern to the Office of the UNHCR. ${ }^{29}$ Asylumseekers form part of UNHCR's competence rationale personae. ${ }^{30}$

They generally take place without proper travel documentation and are often facilitated by smugglers or traffickers. The vessels used for the journey are frequently overcrowded, unseaworthy and not commanded by professional seamen. Distress at sea situations are common, raising grave humanitarian concerns for those involved. Search and rescue operations, disembarkation, processing and the identification of solutions for those rescued are reoccurring challenges for States, international organizations including the UNHCR, IMO, and IOM as well as shipping industry.

The term "boat people" was coined in 1970s to identify the thousands of people who fled Indochina in fishing boats after Vietnam War. Thousands perished at sea, many at the hands of pirates in the Gulf of Thailand. ${ }^{31}$ During that crisis, regional states such as Malaysia refused to allow disembarkation and turned boats back at sea. But in late 1978, all boat people were granted status as refugees of direct concern to the UNHCR, and special resettlement schemes functioned for the following years. ${ }^{32}$

\section{GENERAL LEGAL FRAMEWORK}

Legal framework governing treatment of asylum seekers migrating by sea which includes the scope of search and rescue, and disembarkation of asylum seeker on coastal States, lies on the applicable provisions of international maritime law in interaction with international refugee law and it may touches on international human rights and international criminal law.

\section{International maritime law}

Aiding those in peril at sea which may include asylum seekers is an obligation codified under several conventions relating to international maritime law such as the United Nations Convention on the Law of the Sea of 1982 (UNCLOS), ${ }^{33}$ the International Convention for the Safety of Life at Sea of 1974 (SOLAS) $^{34}$ as amended, the International Convention on Maritime Search and Rescue of 1979 (SAR) as amended, and the 1958 Convention on the High $\mathrm{Sea}^{35}$ (to the 
extent that it has not been superseded by UNCLOS).

These conventions explicitly contain the obligation to come to the assistance of persons in distress at sea. ${ }^{36}$ This obligation is unaffected by the status of the persons in question, their mode of travel or the numbers involved. The ship master is responsible for providing assistance or rescue ${ }^{37}$. Coastal States have the obligation to develop adequate search and rescue services. ${ }^{38}$ The responsibility of flag States can be difficult if it involves issues on flag inconvenience or government ships used for noncommercial purpose. ${ }^{39}$

However, there is a lack of clarity and possible lacuna in international maritime law with regards to continuing steps after vessel has taken people on board $^{40}$. Nevertheless, the issues were addressed when IMO created Guidelines on the Treatment of Rescued Person At Sea in May 2004 ${ }^{41}$ (the Guidelines) reflecting the amendment of SAR and SOLAS in 2004 to address issues on "disembarkation" and "place of safety." 42 It was stated that the primary authority for disembarkation decision lies within the State responsible for search and rescue in the region where the rescue occurs ${ }^{43}$. What this means in practical terms is that the Rescue Co-ordination Centre (RCG) may now designate where disembarkation will occur on behalf of the assisting vessel, regardless of the status of that vessel as private or State-owned, military or nonmilitary.

The Guidelines did not attempt to provide a singular definition of concept of "place of safety" but gave insight into its meaning, for example, a place of safety ${ }^{44}$ is "a location where rescue operations are considered to terminate" or "where survivors' safety of life is no longer threatened and where their basic human needs (such as food, shelter and medical needs) can be met" or "a place from which transportation arrangements can be made for the survivors' next or final destination" or "may be aboard a rescue unit or other suitable vessel or facility at sea can serve as a place of safety until the survivors are disembarked to their next destination. ${ }^{45}$

The Guidelines also discuss the potential conflict between the need to promptly disembark rescued persons and States' non-rescue-related interests in screening such individuals before permitting disembarkation. However, the Guidelines are clear that delivery to a place of safety should take precedence over any non-SAR concerns, ${ }^{46}$ and paragraph 6.20 of the Guidelines suggest that the concern over a rescued individual's refugee status may not be used as ground for delaying disembarkation. ${ }^{47}$ In this sense, it suggests that the responsibility for screening (to identify rescued persons in need of international protection) lies with the State of disembarkation. ${ }^{48}$

International agencies ${ }^{49}$ such as the IMO, UNHCR and IOM have specific but differing responsibilities towards persons rescued-at-sea. The IMO has the widest and most direct set of responsibilities. It oversees the development of international maritime law, with emphasis on safety aspects, providing technical advice and assistance to States to ensure that they respect their obligations. The UNHCR has a specific responsibility to guide and assist states and other actors on the treatment of asylum seekers and refugees found at sea and to monitor compliance with refugee protection responsibilities in such scenarios. The IOM plays a specific role regarding the needs of migrants at sea, as part of its broader mandate to address issues related to migration.

\section{(b) International refugee law}

International refugee law is premised on the understanding that a person has a wellfounded fear of persecution, on specific grounds, before he or she can avail of international protection. $^{50}$ Therefore, clarification status is crucial in the refugee 
context to determine obligations owed to the refugee ${ }^{51}$. A ship master is not the competent authority to determine the status of those who fall under his temporary care after a rescue operation. Ensuring prompt access to fair and efficient asylum procedures is key to ensuring the adequate protection of asylum seekers and refugees amongst those rescued. In European Union, under the European Agenda on Migration the development of "hotspot" in frontline member states was done to ensure that asylum seekers have access to effective individual asylum procedure and providing adequate reception conditions for all asylum seekers. ${ }^{52}$ This was also done to help reducing the irregular onward movements within the European Union.

State responsibility under international refugee law, and in particular the 1951 Convention is activated once it becomes clear that there are asylum seekers among those rescued. The responsibilities of States to ensure admission, at least on temporary basis and to provide for access to asylum procedures is equally applicable to asylum seekers rescue at sea. These responsibilities are provided under the Executive Committee Conclusions of UNHCR's Programme (EXCOM Conclusions) as follow:

1. EXCOM Conclusion No. 22 (1981), Part II A paragraph 2 states "In all cases the fundamental principle on non-refoulement, including non-rejection at the frontier must be scrupulously observed";

2. EXCOM Conclusion No. 82 (1997), paragraph (d) (iii) reiterates "The need to admit refugees into the territories of States, which includes no rejection at frontiers without fair and effective procedures for determining status and protection needs"; and

3. EXCOM Conclusion No. 85 (1998) para (q) states “... reiterates the need to admit refugees to the territory of States, which includes no rejection at frontiers without access to fair and effective procedures for determining status and protection needs".

In the UNHCR's view, the identification and subsequent processing of asylum seekers is most appropriately carried out on dry land. ${ }^{53}$ On board processing may be appropriate in some limited instances depending on the number and conditions of person involved, the facilities of the vessel and its physical location. Onboard processing is inappropriate where the rescued person are aboard a commercial vessel. The first priority in most instances remains prompt and safe disembarkation followed by access to fair and efficient asylum procedures.

In determining the State responsible for admitting asylum seekers, international refugee law read in conjunction with international maritime law suggests that it is generally the State where disembarkation or landing occurs. ${ }^{54}$ Normally, it is the coastal State in the immediate vicinity of the rescue. However, the flag State could also have primary responsibility under certain circumstances. This happens when it is clear that those rescued intended to request asylum from the flag State, then the State could be said to be responsible for responding to the request and providing access to its national asylum procedure. If the number of rescued person is small, it might be reasonable for them to remain in the vessel until they can be disembarked on the territory of the flag State. Alternatively, circumstances might necessitate disembarkation in a third State as a transitional measure without that State assuming any responsibility to receive and process applications. In this context, it is good to note that the EXCOM of the UNHCR adopted six Conclusions specifically on rescue at sea between 1980 and $1985^{55}$. The Conclusions were done to regulate specific situation of refugees and 
asylum-seekers in the South China Sea, and criminal attacks (acts of piracy) inflicted upon them.

Other than that, the EXCOM Conclusions No. 14, 15 and 23 were adopted in conjunction with the obligation under international maritime law to ensure delivery to a place of safety, call upon coastal States to allow disembarkation of rescued asylum seekers at the next port of call. The EXCOM Conclusions are as follow:

1. EXCOM Conclusion No. 14 (1979) paragraph (c) states "that refugees had been rejected at the frontier...in disregard of the principle of non-refoulement and that refugees, arriving by sea had been refused even temporary asylum with resulting danger to their lives ...";

2. EXCOM Conclusion No. 15 (1979), paragraph (c) states "It is the humanitarian obligation of all coastal States to allow vessels in distress to seek haven in their waters and to grant asylum, or at least temporary refuge, to person on board wishing to seek asylum"; and

3. EXCOM Conclusion No. 23 (1981), paragraph 3 states "In accordance with international practice, supported by the relevant international instruments, persons rescued at sea should normally be disembarked at the next port of call. This practice should also be applied in the case of asylumseekers rescued at sea".

It is to be noted that the terms "next port of call" was mentioned in the aforesaid EXCOM Conclusion No. 23 (1981). The terms "next port of call" was not clearly defined and it was discarded during the Expert Roundtable in Lisbon in 2002 and replaced with recommendation "to increase shipmasters' discretion in determining the time and place for disembarkation" 56 . The shipmasters have the "right to expect assistance from coastal States" and "called upon coastal States to provide assistance where requested by rescue vessels. Later, when the Guidelines was introduced in 2004 it does not reflect on disembarkation at the "next port of call" nor "the shipmasters' discretion to where disembarkation should occur". The Guidelines states that "primary authority for disembarkation lies with the State responsible for search and rescue in the region where the rescue occurs. The Guidelines serves as a guidance relating to humanitarian obligations and obligations under the relevant international law on treatment of persons rescued at sea.

\section{(c) International human rights law}

It contains important standards in relation to persons in distress and rescued at sea. The safe and humane treatment of all persons rescued regardless of their legal status or the circumstances in which they were rescued is of paramount importance. Basic principles such as the protection of the right to life, freedom from cruel, inhuman or degrading treatment and respect for family unity by not separating those rescued must be upheld at all times $^{57}$.

\section{(d) International criminal law}

In the international level, the issues of trafficking of persons and smuggling of migrants have been dealt with through the creation of two separate protocols that tackle illegal acts associated with the movement of people. The United Nations Convention against Transnational Organised Crime 2004 (UNODC 2004) contains the Protocol to Prevent, Suppress and Punish Trafficking in Persons, Especially Women and Children, Supplementing the United Nations Convention against Transnational Organized Crime ${ }^{58}$ (the Trafficking Protocol) and the Protocol against the 
Smuggling of Migrants by Land, Sea and Air Supplementing the United Nations Convention against Transnational Organised Crime (the Smuggling Protocol). ${ }^{59}$

According to the definitions contained in these protocols, while trafficking is deemed to occur in both legal and illegal migration streams, and within and across national borders, smuggling only involves the illegal movement of people across national borders. The crucial distinction between the two, however, is the forced labour or slavery-like conditions that always characterize trafficking, which is understood to be inherently exploitative and not incidentally exploitative, as is the case with smuggling. ${ }^{60}$ In reality, however, the boundaries between smuggling and trafficking are far less clear than these definitions suggest. The individuals and groups that manage the recruitment and smuggling of migrants are frequently the same as those involved in human trafficking. ${ }^{61}$ Individuals who have been smuggled may find themselves working in the same industries as persons who have been trafficked and may be subject to the same exploitative practices. Conversely, victims of trafficking may be treated as undocumented migrants if they are caught outside a trafficking context.

Under the Smuggling Protocol, the fact that migrants including asylum seekers and refugees, were smuggled does not deprive them of any rights as regards access to protection and assistance measures. In the context rescue at sea, the rights of those rescued are not unduly restricted as a result of actions designed to tackle the crime of people smuggling. With regards to asylum seekers, the Smuggling Protocol contains general saving clause in Article 19 stating that there is no inherent conflict between the standards set by international law to combat crimes and those contained in international refugee law. ${ }^{62}$

\section{ASYLUM SEEKERS AND UNHCR ROLE IN MALAYSIA}

As of 31 May 2017, a total of 150,204 refugees and asylum seekers from 59 countries have been registered with the UNHCR. Minister in the Prime Minister's Department Datuk Seri Shahidan Kassim said $^{63}$ from the amount, 94,361 were refugees while the remaining 55,843 were asylum seekers. 10 countries made up the majority of refugees and asylum seekers, with the highest coming from Myanmar (133,725 people); Pakistan 3,548; Sri Lanka 2,328; Yemen 2,095; Somalia 2,062; Syria 1,980; Iraq 1,461; Afghanistan 1,082; Palestine 698; and Iran 440. These figures illustrate Malaysia's role as a major destination country for refugees and asylum seekers.

To date Malaysia has not ratified the 1951 Convention and 1967 Protocol $^{64}$. As a result, refugees are generally being considered to be irregular migrants. The unsatisfactory nature of Malaysia's refugee protection sometimes prompt migrants to seek protection in other countries. This problem of mistreatment appears to be prevalent whereby immigration officials, police officers and paramilitary volunteer corps members (RELA) are frequently accused of harassing refugees. The possession of official UNHCR refugee cards has been said to provide little protection against abuse. ${ }^{65}$ Be that as it may, it is important to note that asylum seekers have always been granted an exemption order under the Immigration Act 1959/1963 [Act 155] so that the person can stay at a specific location in Malaysia during specific time prescribed. $^{66}$

Life of asylum seekers varied between communities. Generally, they receive no direct financial support for housing and food from the UNHCR. They must find illegal work to support themselves and families. Some often relying on family and friends resettled to the West for survival Refugees from 
Myanmar are the vast majority of refugees and asylum seekers in Malaysia. They are very well organized, maintain community organization and provide array of services in combination with local NGOs.

Although Malaysia is not a state party to the 1951 Convention and 1967 Protocol, the Malaysian Government continues to cooperate with the UNHCR in addressing refugee and asylum seekers issues on humanitarian grounds. As Malaysia has no legal framework in place to regulate status of refugees and asylum seekers, the UNHCR conducts all activities related to reception, registration, documentation and status determination of asylum seekers in Malaysia.

The UNHCR began operation in Malaysia since 1975 when Vietnam began to arrive. The UNHCR assisted the Malaysian Government in 1975-1996 in providing protection and assistance for Vietnamese, in 1975-1980 for receiving and locally settling 50,000 Filipino Muslims from Mindanao, in 1980 in locally settling the Muslim Chams from Cambodia and in 1990 in handling Bosnian refugees.

\section{TRAFFICKING AND SMUGGLING OF ASYLUM SEEKERS}

Nation states have a vested interest in maintaining the distinction between human trafficking and people smuggling because it provides a clear basis on which to maintain border control. Human trafficking and people-smuggling laws thus seek to restrict immigration by prosecuting illegal entries (those who have been smuggled) or rehabilitating and repatriating 'victims' of trafficking.

In the international level, Malaysia has ratified the United Nations Convention against Transnational Organised Crime on 24 September $2004^{67}$ and the Trafficking Protocol on 26 February $2009,{ }^{68}$ but has yet to ratify the Smuggling Protocol. ${ }^{69}$ Malaysia is home to a large undocumented migrant population, consisting of temporary labour migrants, refugees and displaced persons, and victims of trafficking, as well as a large documented migrant labour workforce. ${ }^{70}$ To address international criticism and to improve the treatment of victims of trafficking, the Malaysian Government introduced the Anti-Trafficking in Persons Act 2007 [Act 670] in 2007 pursuant to the Trafficking Protocol, ${ }^{71}$ which was subsequently amended in $2010^{72}$ and $2015^{73}$ to include crimes associated with migrant smuggling and currently known as the "Anti-Trafficking in Persons and Anti-Smuggling of Migrants Act 2007 [Act 670]”.

Under Act 670, courts have jurisdiction to hear prosecutions of any person charged with an offense under the Act, whether or not the alleged offense occurred within or outside Malaysia and regardless of the nationality of the offender, if Malaysia is a receiving country, transit country, or if the trafficking starts in Malaysia. ${ }^{74}$ Part II of Act 670 established the Council for AntiTrafficking in Persons and AntiSmuggling of Migrants, commonly referred to as MAPO, which consists of various government officials and five representatives from nongovernmental organizations. $^{75}$ The 2015 amendments added a new Part IA to Act 670, establishing a High Level Committee of certain government ministers that is tasked with deliberating on and making decisions regarding recommendations made by MAPO. Part III of Act 670 sets out a number of offenses related to trafficking in persons, while Part IV relates to enforcement. $^{76}$ A trafficked person is immune from prosecution in relation to illegally entering the receiving or transit country, unlawful residence in a country, or his or her procurement or possession of any fraudulent travel or identity document $^{77}$. Similar types of offenses related to smuggling of migrants are contained in Part IIIA of the Act. There is 
no immunity provision applicable to smuggled migrants in this Part.

Part IV relates to enforcement of the legislation. Part V of the Act, related to the care and protection of trafficked persons, makes provision for the appointment of social welfare officers as Protection Officers. There are also provisions relating to protection orders, whereby a person is placed at a shelter home, and for the medical treatment and hospitalization of trafficked persons. A new provision, added by the 2015 amendment legislation, enables trafficked persons to be given permission by MAPO to move freely or to be employed outside of refuges. ${ }^{78}$ The 2015 amendment legislation added provisions to this Part that enable a court to order a person convicted of an offense under the Act to pay compensation to the trafficked person $^{79}$. Where there is no conviction, a person can still be ordered to pay any wages in arrears to the trafficked person. 80

Other legislation that may be invoked to prosecute trafficking or trafficking-related offenses include the Penal Code [Act 574], which criminalizes trafficking for the purposes of prostitution along with other prostitution-related offenses, forced labor, and habitual dealing in slaves; the Employment Act 1955 [Act 265], which contains minimum labor protection standards and provisions related to domestic servants; the Children and Young Persons (Employment) Act [Act 350], which provides for limited employment of children in light work in certain sectors; the Private Employment Agencies Act 1981 [Act 246], which regulates recruitment agencies and grants the Director General of Labour investigatory and inspection powers; the Child Act 2001 [Act 611], which prohibits exploitative acts, custody transfers for any valuable consideration, and bringing a child into Malaysia on false pretenses as well as taking a child out of Malaysia without parental consent; the Passports Act 1966 [Act 150], which criminalizes the withholding of passports; as well as the Immigration Act 1959/63 [Act 155], Maritime Enforcement Agency Act 2004 [Act 633], Customs Act 1967 [Act 235], Security Offenses (Special Measures) Act 2012 [Act 747], and the Anti-Money Laundering and Anti-Terrorism Financing Act 2001 [Act 613].

The United States (US) releases an annual Trafficking in Persons (TIP) Report that is commissioned by the US Government and provides an annual snapshot of the circumstances of each country in relation to human trafficking ${ }^{81}$. In 2017, the US Government has removed Malaysia from the Tier 2 Watch List in the TIP Report ${ }^{82}$. But, Malaysia however remains in Tier 2 in the 2017 TIP Report ${ }^{83}$ which states that-

"The Government of Malaysia does not fully meet the minimum standards for the elimination of trafficking; however, it is making significant efforts to do so. The Government demonstrated increasing efforts compared to the previous reporting period; therefore, Malaysia was upgraded to Tier 2. The government demonstrated increasing efforts by expanding trafficking investigations, prosecutions, and convictions...However, the government did not meet the minimum standards in several key areas. The government's victim protection efforts remained largely inadequate. Newly implemented laws created a process for shelter residents to move freely and to work if they are cleared by medical, security, and mental health professionals and approved by the antitrafficking council (MAPO). However, bureaucratic delays, including a lack of counselors able to complete required mental health evaluations; risk-averse and paternalistic attitudes towards victims; and lack of victim interest in available work opportunities resulted in a very low number of victims being granted the right to work and/or to move freely."

In addition to that, the 2017 TIP Report states that- 
"The 2007 Anti-Trafficking in Persons Actamended in 2010 and 2015-prohibits all forms of human trafficking and prescribes punishments of up to 20 years imprisonment, which are sufficiently stringent and commensurate with those prescribed for other serious offenses, such as rape. The AG approved and the DPM enforced implementing regulations for the amendments to the antitrafficking law. The amendments allow victims - at the discretion of the antitrafficking council-to work and to move freely in and out of government facilities, pending a security risk assessment, medical screening, and mental health evaluation; allow the court to order convicted traffickers to pay restitution to their victims and provide an avenue for victims to bring civil suits against their abusers; expand interim protection orders from 14 to 21 days to allow for more thorough investigations; allow NGOs to serve as designated protection officers; and institutionalize a high-level anti-trafficking committee. Complicity among law enforcement officials, in the form of accepting bribes to allow undocumented border crossings, hampered some anti-trafficking efforts. The government detained 42 immigration and police officers for their involvement in facilitating smuggling and trafficking crimes ...”

In relation to asylum seekers in Malaysia, the 2017 TIP Report states that-

"The more than 150,000 registered refugees and asylum-seekers in Malaysia lack formal status and the ability to obtain legal work permits, leaving them vulnerable to trafficking. Many refugees incur large

\section{NOTES}

1 K. Newland, Troubled Waters: Rescue of Asylum Seekers and Refugees at Sea, 2003.

2 K. Newland, 2003

3 The Guardian, Migrant Sea Route to Italy is World's Most Lethal, https:/ /www.the guardian.com/ world/2017/sep/11/migrantdeath-toll-rises-after-clampdown-on-easteuropean-borders (Published on 11 September 2017) (Accessed on 23 November 2017).

4 United Nations High Commissioner for Refugees (UNHCR), The UN Refugee Agency, smuggling debts, which traffickers use to subject some refugees to debt bondage. Children from refugee communities in peninsular Malaysia are reportedly subjected to force-begging. A large population of Filipino Muslims resides illegally in Sabah, some of whom are vulnerable to trafficking. Few Malaysian citizens are subjected to trafficking internally and abroad."

\section{CONCLUSION}

In conclusion, it is observed that the issues relating to asylum seekers migrating by sea have been a major challenges to UNHCR, IMO, IOM and States especially to Malaysia. The writers of the opinion that whether the asylum seekers are being smuggled or trafficked, it does not forfeit their rights to be protected under the relevant international and domestic laws. Indeed, asylum seekers need protection against these abuses. Be that as it may, the persistent efforts made by UNHCR, IMO and IOM to strengthen asylum seekers' rights in the area of rescue-at-sea and disembarkation, clearly show their commitments in protecting the helpless asylum seekers. In addition to that, Malaysia has shown tremendous effort in combatting human trafficking and smuggling of asylum seekers by amending the Act 670 in order to achieve the standards provided by the US Government under TIP Report in eliminating trafficking and smuggling of migrants in the near future.

Mixed Movements in South-East Asia 2106 https://reliefweb.int/sites/reliefweb.int/files/reso urces/UNHCR\%20-\%20 Mixed\% 20 Movements\%20in\%20SouthEast\%20Asia\%20-\%202016\%20-\%20April\%202017_0.pdf (Accessed on 23 November 2017).

5 International Organization for Migration (IOM), https://www.iom.int/key-migrationterms (Accessed on 3 November 2017).

6 UNHCR, Key message: Who is a Refugee, http://www.unhcr.org/4d944d089.pdf (Accessed on 27 November 2017). 
7 H.R. Council, P. Garg, T. Thapa and J. Chu, 2014, http://www.woodstockschool.in/studentrun-ws-mun-back/ (Accessed on 17 November 2017).

8 Article 1(2) of the 1951 Convention relating to the Status of Refugees.

9 M. Pugh, Drowning not Waving: Boat People and Humanitarianism at Sea (2004) 17 (1) Journal of Refugee Studies, Oxford University Press: UK p 62.

10 The Guardian, Migrants, Refugees and Asylum Seekers: What's the Difference? https:/www.theguardiancom/world/2015/aug/ 28/migrants-refugees-and-asylum-seekerswhats-the-difference (Published on 28 August 2015) (Accessed on 13 December 2017).

11 UNHCR, State Parties to the 1951 Convention relating to the Status of Refugees and 1967 Protocol, http://www.unhcr.org/enmy/protection /basic/3b73b0d63/states-parties1951-convention-its-1967-protocol.html

(Accessed on 17 December 2017).

12 Article 1 "Refugee is someone who is unable to or unwilling to return to their country of origin owing to a well-founded fear of being persecuted for reasons of race, religion, nationality, membership of a particular social group or political opinion".

13 New Straits Times, https://www.nst.com.m y/news/nation/2017/07/260905/more-150000unhcr-registeredrefugees-asylum-seekers-mala ysia (Published on 26 July 2017) (Accessed on 18 December 2017).

14 Ref World, http://www.refworld.org/docid/4 $157 \mathrm{e} 75 \mathrm{e} 4 . \mathrm{html}$ (Accessed on 28 December 2017).

15 Asylum Seekers Resource Centre, Temporary Protection Visa, https://www.asrc.org.au/resources/factsheet/temporary-protection-visas/ (Accessed on 18 December 2017).

16 Refugee Council of Australia, https://www.refugeecouncil.org.au/r/pb/THC_1 40206.pdf (Accessed on 18 December 2017).

17 European Commission, Asylum Procedures, https://ec.europa.eu/home-affairs/what-wedo/policies/ asylum/common-procedures_en (Accessed on 25 December 2017).

18 UNHCR, Handbook on Procedures and Criteria for Determining Refugee Status under the 1951 Convention and the 1967 Protocol relating to the Status of Refugees, http://www.unhcr.org/4d93528a9.pdf (Accessed on 18 December 2017).

19 UNHCR, Handbook on Procedures and Criteria for Determining Refugee Status under the 1951 Convention and the 1967 Protocol relating to the Status of Refugees, p 3.
Asylumaid, Appeal Rights, https://www.asylumaid.org.uk/the-asylumprocess-made-simple/\#Appeal (Accessed on 18 December 2017).

21 Justice and Government New Zealand, Immigration and Protection Tribunal, https://www.justice. govt.nz/tribunals/immigratio /immigration-andprotection/ (Accessed on 18 December 2017).

22 Rights Info, Human Rights for All: The Rights of Asylum Seekers in the UK, https://rightsinfo.org/ rights asylum-seekers/ (Accessed on 18 December 2017).

23 UNHCR, Rights and Obligations as Asylum Seekers, http://help.unhcr.org/greece/rightsand-duties/rights-and-duties-of-asylum-seekers/ (Accessed on 18 December 2017).

24 C. Schneider, S. Joos and K. Bozorgmehr, Disparities in Health and Access to Healthcare between Asylum Seekers and Residents in Germany: A Population-Based Cross-Sectional Feasibility Study, 2015.

Refugee Council, Destitution Support, https://w ww.refugeecouncil.org.uk/what_ we_do/multilingual_ advice_for_asylum_seekers/destitution_support (Accessed on 18 December 2017).

26 J. Kumin, The Challenge of Mixed Migration by Sea (2014) 45 FMR. p 49.

27 K.Newland, Protection at Sea: Addressing Irregular Maritime Migration, 2014, https://www.migrationpolicy.org/news/protectio n-sea-addressing-irregular-maritime-migration (Accessed on 10 October 2017).

28 J. Kumin, The Challenge of Mixed Migration by Sea, 2014

29 UNHCR, Refugees and Asylum-Seekers in Distress at Sea - How Best to Respond? Expert Meeting in Djbouti 8-10 November 2011

30 UNHCR, Background Note Concerning the Competence of the United Nations High Commissioner for Refugees (UNHCR) in relation to Rescue-at-Sea Matters, Prepared for COMSAR 6, Working Group 1.

31 T. Kushner and K. Knox, Refugees in an Age of Genocide: Global, National and Local Perspectives London: Frank Cass, 1999.

32 M. Pugh, Drowning not Waving: Boat People and Humanitarianism at Sea (2004) 17 (1) Journal of Refugee Studies, Oxford University Press: UK.

33 United Nations, United Nations Convention on Law of the Sea, http://www.un.org/depts/ los/convention_agreements/texts/unclos/unclos _e.pdf (Accessed on 13 December 2017).

34 International Maritime Organization (IMO), http://www.imo.org/en/About/conventions/ listofconven tions/pages/international- 
convention-for-the-safety-of-life-at-sea-(solas),1974.aspx (Accessed on 13 December 2017).

35 Office of General Counsel of National Oceanic and Atmospheric Administration, http://www.gc.

noaa.gov/documents/8_1_1958_high_seas.pdf (Accessed on 13 December 2017).

36 Paragraph 2.1.1 of Chapter of the Annex to SAR, Regulation 15 of Chapter V of the Annex to SOLAS and Article 98(1) of UNCLOS.

37 Article 98(1) of the UNCLOS.

38 Article 98(2).

39 Article 6 and 9 of the Convention of High Sea 1958,http://www.gc.noaa.gov/documents/8_1

_1958_ high_seas.pdf (Accessed on 22 December 2017).

40 UNHCR,Background Note on the Protection of Asylum Seekers and Refugees Rescued at Sea, 2002, p 4.

41 IMO, Guidelines on the Treatment of Rescued Person At Sea.

42 B. Miltner, Irregular Maritime Migration: Refugee Protection Issues in Rescue and Interception (2006) $30 \quad$ (1) Fordham International Law Journal, p 108.

43 IMO, Guidelines of the Treatment of Persons Rescued at Sea (Adopted on 20 May 2004) MSC 78/26/Add.2 Annex 34 page 2, http://www.imo.org/en/KnowledgeCentre/Index ofIMOResolutions/Maritime-Safety-

Committee-

(MSC)/Documents/MSC.167(78).pdf

(Accessed on 22 December 2017) states that-

"REALIZING FURTHER that the intent of the new paragraph 1-1 of SOLAS regulation V/33, as adopted by resolution MSC. 153(78) and paragraph 3.1.9 of the Annex to the SAR Convention as adopted by resolution MSC.155(78), is to ensure that in every case a place of safety is provided within a reasonable time. It is further intended that the responsibility to provide a place of safety, or to ensure that a place of safety is provided, falls on the Contracting Government/Party responsible for the SAR region in which the survivors were recovered."

44 Paragraph 6.12 of the Guidelines on the Treatment of Rescued Person At Sea.

45 Paragraph 6.14.

46 Paragraph 6.20.

47 B. Miltner, Irregular Maritime Migration: Refugee Protection Issues in Rescue and Interception, 2006, p 111.

48 B. Miltner, 2006

49 UNHCR, Background Note on the Protection of Asylum Seekers and Refugees Rescued at Sea (2002) p 3

50 UNHCR, Protecting Refugees: Questions and Answers, http://www.unhcr.org/afr/publicatio ns/brochurs /3b779dfe2/protecting-refugeesquestions-answers.html (Accessed on 19 December 2017).

${ }^{51}$ UNHCR, Background Note on the Protection of Asylum Seekers and Refugees Rescued at Sea, 2002, p 5.

52 Amnesty International, A Union of Protection: Amnesty International's Agenda for Refugees Protection in Europe, https://www.amnesty.ie/wpcontent/uploads/2016/04/A-Union-OfProtection-AI-Agenda-for-Refugee-Protectionin-Europe.pdf (Accessed on 19 December 2017).

53 UNHCR, Background Note on the Protection of Asylum Seekers and Refugees Rescued at Sea (2002) p 6.

54 UNHCR,2002

55 UNHCR, EXCOM Conclusion No. 20, 23, 26, 31, 34 and 38, http://www.refworld.org/pdfid/ 4b2 8bf1f2.pdf (Accessed on 19 December 2017).

B. Miltner, Irregular Maritime Migration: Refugee Protection Issues in Rescue and Interception, 2006, p 107.

57 EXCOM Conclusion No. 93 (2002).

58 Organization for Security and Co-operation in Europe (OSCE) , https://www.osce.org/ odihr/19223? download=true $($ Accessed on 22 December 2017).

59 United Nations, https://www.unodc.org/docum ents/southeastasiaandpacific/2011/04/somindonesia/ convention_smug_eng.pdf (Accessed on 19 December 2017).

60 K. Kempadoo, 'Introduction: From Moral Panic to Global Justice: Changing Perspectives on Trafficking' In K. Kempadoo, B. Pattanaik and J. Sanghera (eds) Trafficking and Prostitution Reconsidered: New Perspectives on Migration, Sex Work, and Human Rights, Boulder, CO: Paradigm Publishers, 2005, p vii-xxxiv.

61 L. Lyons and M. Ford, Trafficking Versus Smuggling: Malaysia's Anti-Trafficking in Persons Act. In Sallie Yea (Eds.), Human Trafficking in Asia: Forcing Issues, (pp. 35-48). London and New York: Routledge, 2014, https://ses.library.usyd.edu.au/bitstream/2123/1 6337/2/Postprint_Trafficking\%20Versus\%20

Smug gling.pdf (Accessed on 19 December 2017).

62 Article 19(1) the Protocol against the Smuggling of Migrants by Land, Sea and Air 2000 "Nothing in this Protocol shall affect the other rights, obligations and responsibilities of States and individuals under international law, including international humanitarian law and international human rights law and, in 
particular, where applicable, the 1951 Convention and the 1967 Protocol relating to the Status of Refugees and the principle of nonrefoulement as contained therein.".

63 New Straits Times, https://www.nst.com.my/ne ws/nation/2017/07/260905/more-150000-unhcrregistered-refugees-asylum-seekers-malaysia (Published on 26 July 2017) (Accessed on 18 December 2017).

64 E. Solomon, Migrant Smuggling into Malaysia: Lessons from the Andaman Sea Crisis, 2017. http://www.internationalaffairs.org.au/newsitem/migrant-smuggling-into-malaysia-lessonsfrom-the-andaman-sea-crisis (Accessed on 15 November 2017).

65 Amnesty Organization, https://www.amnesty .org/en/press-releases/2010/06/malaysiarefugees-arrested-abused-and-denied-rightwork/ (Accessed on 22 December 2017).

66 Immigration (Exemption) (Asylum Seekers) Order 2011 [P.U. (A) 267/2011].

67 UN,https://treaties.un.org/pages/Vi ewDetails.aspx?src=TREATY\&mtdsg_no=XVI II-12\&chapter $=18 \&$ clang=_en (Accessed on 22 December 2017).

$68 \mathrm{UN}$, https://treaties.un.org/pages/ViewDetails .aspx?src=TREATY\&mtdsg_no=XVIII-12a\&chapter=18 \&clang=_en (Accessed on 22 December 2017).

69 UN, https://treaties.un.org/Pages/ViewDetails.as px?src=TREATY\&mtdsg_no=XVIII-12b\&chapter $=18$ \& clang=_en (Accessed on 22 December 2017).

70 M. Ford, Constructing Legality: The Management of Irregular Labour Migration in Thailand and Malaysia In van der Linden, M. (ed.) In van der Linden, M. (ed.) Labour History Beyond Borders: Concepts and Explorations, Leipzig: Akademische Yerlagsanstalt, 2010, pp. 177-99.

71 Library of Congress, https://www.loc.gov/l aw/help/human-trafficking/malaysia.php (Accessed on 22 December 2017).

72 Attorney General's Chambers (AGC), Act A1385, http://www.agc.gov.my/agcportal/uploads/ files/Publications/LOM/EN/Act\%20670.pdf (Accessed on 22 December 2017)

73 AGC, Act A1500, http://www.federalgazette .agc.gov.my/outputaktap/20151102_1500_BI_ WJW00 5504\%20BI.pdf.

74 Section 3 of the Act 670.

75 Section 6.

76 Section 27-41.

77 Section 25.

78 Section 51A.

79 Section 66A.

80 Section 66B.
81 E. Solomon, Migrant Smuggling into Malaysia: Lessons from the Andaman Sea Crisis, 2017, http://www.internationalaffairs.org.au/newsitem/migrant-smuggling-into-malaysia-lessonsfrom-the-andaman-sea-crisis (Accessed on 15 November 2017).

82 Berita Daily, http://www.beritadaily.com/usupgrades-msia-in-human-trafficking-report/ (Published 28 Jun 2017) (Accessed on 22 December 2017).

83 US Department of State, https://www.state.gov/j/tip/rls/tiprpt/countries/2 017/271235.htm (Accessed on 22 December 2017).

\section{REFERENCES}

Amnesty International, A Union of Protection: Amnesty International's Agenda for Refugees Protection in Europe, https://www.amnesty.ie/wpcontent/uploads/2016/04/A-UnionOf-Protection-AI-Agenda-forRefugee-Protection-in-Europe.pdf

Amnesty Organization, Malaysia Refugees Arrested Abused and Denied Right at Work, https://www.amnesty.org/en/pressreleases/2010/06/malaysiarefugees-arrested-abused-anddenied-right-work/

Attorney General's Chambers, Act A1385 http://www.agc.gov.my/ agcportal/ uploads/

files/Publications/LOM/EN/Act\%2 0670.pdf

AGC, Act A1500, http://www.feder algazette.agc.gov.my /outputaktap /20151102_1500_BI_WJW00550 4\%20BI.pdf

Asylumaid, Appeal Rights, https://www.asylumaid.org.uk/theasylum-process-made-simple/\# Appeal Asylum Seekers Resource Centre, Temporary Protection Visa, https://www.

asrc.org.au/resources/factsheet/temporary-protection-visas/ 
Berita Daily, http://www.beritadaily.com /us-upgrades-msia-in-humantrafficking-report/

European Commission, Asylum Procedures, https://ec.europa.eu/homeaffairs/what-we-do/ policies/asylum/commonprocedures_en

Ford, M. 2010. Constructing Legality: The Management of Irregular Labour Migration in Thailand and Malaysia In van der Linden, $M$. (ed.) In van der Linden, M. (ed.) Labour History Beyond Borders: Concepts and Explorations, Leipzig: Akademische Yerlagsanstalt

Garg, P. H. R., Council,, T. Thapa and J. Chu, 2014. http://www.woodstock school.in/student-run-ws-munback/

International Maritime Organization (IMO), http://www.imo.org/en/About/ conventions/listof conventions/pages/internationalconvention-for-the-safety-of-lifeat-sea-(solas),-1974.aspx

International Organization for Migration (IOM), https://www.iom.int/keymigration-terms

Justice and Government NZ, Immigration and Protection Tribunal, https://www.justice.govt.

nz/tribunals/immigration/immigrati on-and-protection/

Kempadoo K., 2005. 'Introduction: From Moral Panic to Global Justice: Changing Perspectives on Trafficking' In K. Kempadoo, B. Pattanaik and J. Sanghera (eds) Trafficking and Prostitution Reconsidered: New Perspectives on Migration, Sex Work, and Human Rights, Boulder, CO: Paradigm Publishers

Kumin, J. 2014. The Challenge of Mixed Migration by Sea FMR 45.
Kushner T. and K. Knox, 1999. Refugees in an Age of Genocide: Global, National and Local Perspectives London: Frank Cass

Library of Congress, https://www.loc.gov/law/help/hum an-trafficking/malaysia.php

Lyons L. and M. Ford, 2014. Trafficking Versus Smuggling: Malaysia's Anti-Trafficking in Persons Act In Sallie Yea (Eds.), Human Trafficking in Asia: Forcing Issues, (pp. 35-48). London and New York: Routledge, https://ses.library.usyd.edu.au/ bitstream/2123/

16337/2/Postprint_Trafficking\%20 Versus\%20Smuggling.pdf

Miltner B., 2006. Irregular Maritime Migration: Refugee Protection Issues in Rescue and Interception Fordham International Law Journal, Volume 30, Issue 1 Article 3

Newland K., 2014. Protection at Sea: Addressing Irregular Maritime Migration.https://www.migrationp olicy.org/news/protection-seaaddressing-irregular-maritimemigration

Newland, K. 2003. Troubled Waters: Rescue of Asylum Seekers and Refugees at Sea

New Straits Times, https://www.nst.com.my/news/nati on/2017/07/260905/more-150000unhcr-registered-refugees-asylumseekers-malaysia

Office of General Counsel of National Oceanic and Atmospheric Administration, http://www.gc.noaa.gov/documents /8_1_1958_high_seas.pdf

Organization for Security and Cooperation in Europe (OSCE), https:// www. osce. org/odihr /19223?download=true

Pugh, M. 2004. Drowning not Waving: Boat people and humanitarianism 
at sea. Journal of Refugee Studies 17(1).

Ref World, http://www.refworld.or $\mathrm{g} / \mathrm{docid} / 4157 \mathrm{e} 75 \mathrm{e} 4 . \mathrm{html}$

Refugee Council, Destitution Support https://www.refugeecouncil.

org.uk/

what_we_do/multilingual_advice_f or_asylum_seekers/destitution_sup port

Refugee Council of Australia, https://www.refugeecouncil.org.au/ r/pb/THC_140206.pdf

Rights Info, Human Rights for All: The Rights of Asylum Seekers in the UK, https://rightsinfo.org/rightsasylum-seekers/

Schneider, C., Joos, S. and Bozorgmehr, K. 2015. Disparities in Health and Access to Healthcare between Asylum Seekers and Residents in Germany: A Population-Based Cross-Sectional Feasibility Study

Solomon, E. 2017. Migrant Smuggling into Malaysia: Lessons from the Andaman Sea Crisis http://www.internationalaffairs.org. au/news-item/migrant-smugglinginto-malaysia-lessons-from-theandaman-sea-crisis

The Guardian. Migrants, Refugees and Asylum Seekers: What's the Difference?

https://www.theguardian.com/worl d/2015/aug/28/migrants-refugeesand-asylum-seekers-whats-thedifference

The Guardian. Migrant Sea Route to Italy is World's Most Lethal, https://www.

theguardian.com/world/2017/sep/1

1/migrant-death-toll-rises-afterclampdown-on-east-europeanbordersUnited Nations (UN), https://www.unodc.org/documents/ southeastasiaandpacific/2011/04/so mindonesia/convention_smug_eng.p df
UN,https://treaties.un.org/pages/ViewDeta ils.aspx?src=TREATY\&mtdsg_no $=$ XVIII-12\& chapter $=18 \&$ clang=_en

UN, United Nations Convention on Law of the Sea, http:/ www. un.org /depts/ los/convention_agreements/texts/u nclos/unclos_e.pdf

United Nations High Commissioner for Refugees (UNHCR), Background Note Concerning the Competence of the United Nations High Commissioner for Refugees (UNHCR) in relation to Rescue-atSea Matters, Prepared for COMSAR 6, Working Group 1

UNHCR, Handbook on Procedures and Criteria for Determining Refugee Status under the 1951 Convention and the 1967 Protocol relating to the Status of Refugees, http://www.unhcr.org/4d93528a9.p df

UNHCR, Key message: Who is a refugee, http://www.unhcr.org/4d944d089.p df

UNHCR, Protecting Refugees: Questions and Answers, http://www.unhcr. org/afr/publications/ brochures/3b779dfe2/protectingrefugees-questions-answers.html

UNHCR, Refugees and Asylum-Seekers in Distress at Sea - How Best to Respond? Expert Meeting in Djbouti 8-10 November 2011

UNHCR, Rights and Obligations as Asylum Seekers, http://help.unhcr.org/greece/rightsand-duties/rights-and-duties-ofasylum-seekers/

UNHCR, State Parties to the 1951 Convention relating to the Status of Refugees and 1967 Protocol, http://www.unhcr.org/en$\mathrm{my} /$ protection/basic/3b73b0d63/sta tes-parties-1951-convention-its1967-protocol.html

UNHCR, The UN Refugee Agency, Mixed Movements in South-East Asia 
2106 https:/ /reliefweb.int/sites/ reliefweb.int/files/resources/UNHC R\%20-\%20Mixed\%20

Movements\%20in\%20South-

East\%20Asia\%20-\%202016\%20-$\% 20$ April\% 202017 0. pdf

US Department of State, https://www.st ate.gov/j/tip/rls/tiprpt/countries/201 7/271235.htm

Farah Nurul Ayu Binti Izany

Faculty of Law

Universiti Kebangsaan Malaysia

436000 UKM Bangi, Selangor

Email: farahayu_82@yahoo.com

Rohani Abdul Rahim

Faculty of Law

Universiti Kebangsaan Malaysia 436000 UKM Bangi, Selangor

Email: rar@ukm.edu.my

Annalisa Yahanan

Faculty of Law

Universiti Kebangsaan Malaysia

436000 UKM Bangi, Selangor

Email: annalisa_yahanan@yahoo.com

Azizah Landa

Faculty of Law

Universiti Kebangsaan Malaysia

436000 UKM Bangi, Selangor

Email: Azizah.Landa@sabah.gov.my 